\title{
Adaptive Management in Discourse: The case of involvement discourse markers in English and Spanish conversations*
}

\section{Jesús Romero-Trillo}

Universidad Autónoma de Madrid. Departamento de Filología Inglesa 28049 Madrid. Spain

jesus.romero@uam.es

\begin{abstract}
This article describes the process of adaptive management in discourse as the main tool used by speakers to reformulate ideas in speech, mainly via discourse markers. Discourse markers, therefore, present themselves as elements that by their operative or involvement specificity serve to reshape the cognitive stance of the speaker-listener in a given context. This capacity is especially important to be understood and fostered in the case of non-native learners of a language, as they need to master the pragmatic aspects of a new language and not only its syntactic and semantic components. The article will delve into the comparison of involvement markers in English and Spanish to determine the functional differences in both languages. The results show the pragmatic asymmetry in the use of discourse markers in English and Spanish, a fact that indicates the importance of invigorating this research for the benefit of contrastive and pedagogic studies.
\end{abstract}

Key words: discourse markers, contrastive pragmatics, involvement markers, adaptive management, English, Spanish.

\section{Table of Contents}

\section{Introduction}

2. Adaptive Management and the dynamics of discourse markers

3. Operative and Involvement Discourse Markers
4. Analysis of the Data

5. Discussion

References

\section{Introduction}

Discourse markers have been profusely described and analysed in the last two decades according to different perspectives. However, the variety and richness of discourse markers in speech and their multifaceted functions still pose several methodological and descriptive problems (for an extended discussion on the nature of discourse markers and, specifically, on different traditions see Fischer 2006 and

* I am grateful to the editor, M.J. Cuenca, and to the anonymous referees for their suggestions on the final version of this article. 
Romero-Trillo 2006). In this line, I propose a different approach to discourse markers: the discourse-cognitive model. In this model, discourse markers are defined as "elements that fill the discoursal and cognitive slots that spoken language needs in order to weave the net of interaction" (Romero-Trillo 2006: 640). This approach is geared to the description of the dynamics of discourse and the cognitive status of the markers (Romero-Trillo 1994, 2001). In other words, this view would regard discourse markers as dynamic elements that serve to mould the cognitive stance of the speaker-hearer relationship according to the pragmatic force of an utterance in a given context. For this reason, the key to this model is that discourse markers are the elements that guarantee the "adaptive management" of the message to a discourse situation.

\section{Adaptive Management and the dynamics of discourse markers}

Adaptive Management is a concept borrowed from recent developments in theoretical ecology that can be defined as follows:

Adaptive Management is a systematic process for continually improving management policies and practices by learning from the outcomes of operational programs. Its most effective form -"active" adaptive management- employs management programs that are designed to experimentally compare selected policies or practices, by evaluating alternative hypotheses about the system being managed.

(Ministry of Forests and Range, Government of British Columbia; http://www.for.gov.bc.ca/hfp/amhome/Amdefs.htm)

The standard model of adaptation that ecology suggest for the correct application of the management practices, as presented in the website mentioned above, is the following:

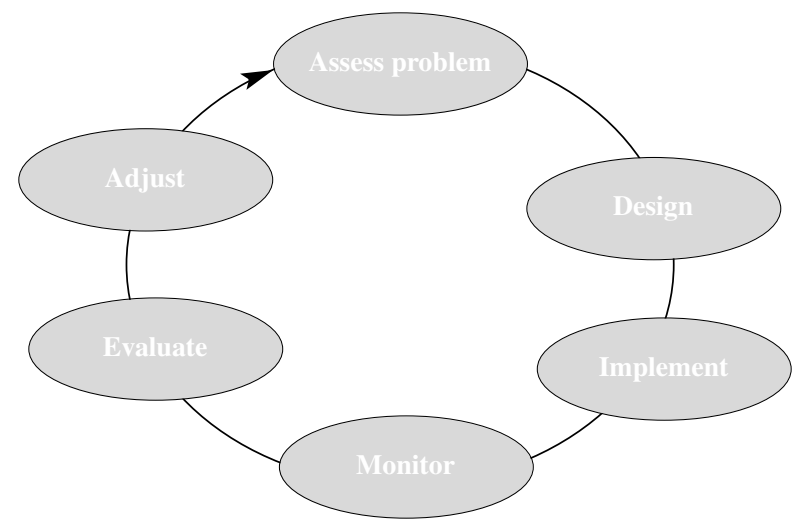

Figure 1. The Standard Model of Adaptation. 
I believe that the Adaptive Management process presented in the figure 1 is perfectly applicable to spoken language as it reflects the method that a speaker uses to repair misunderstandings in a specific moment of the language exchange. Therefore, "Adaptive Management in Discourse" can be defined as the capacity of a speaker to adapt the grammatical, lexical and pragmatic parameters of discourse through a series of remedial elements and through a principled process, in order to comply with the demands of a new cognitive stage in a conversation via a cognitive standardised process.

This view of discourse is rooted in the conception of language as a dynamic system that is formed of different patterns, where the patterns are the elements that govern the substance (the sound) and the structure (the word, the phrase, etc.) and map the relationships that exist between them. The first feature of this pattern is that it forms a network of non-linear ${ }^{1}$ relationships that self-regulate via feedback. In my opinion, this is the true essence of discourse markers in conversation because they are used by speakers to adjust and modify the illocutionary force of an utterance at points where the optimal communication may falter. In fact, self-regulation is the most important feature of all living organisms because it is the essential tool that guarantees survival along time, and communication - a living organism - is always at risk by the presence of misunderstanding and silence. Metaphorically speaking, therefore, discourse markers are the self-regulating elements that enter the structure to help keep a conversation alive. This can be clearly seen in the case when speakers have finished a topic and utter discourse markers such as well, $m$, yeah, etc., instead of letting silence prevail.

Another important fact regarding self-regulation, according to McCulloch and Pitts (1943), is the role of binary relations in the neural network. This discovery is also applicable to the functioning of discourse markers since they also behave in a binary track with respect to conversation: the first one is their presence/absence, and the second is the specific intonation with which they are pronounced. This dual behaviour defines the parameters that are essential to understand their function in the conversation process.

Therefore, discourse markers are not "extra" elements that appear in language to "decorate or mar speech", or only in the cases when the speaker is thinking what to say next (as in the case of $\mathrm{ahm}, \mathrm{ehm}$ ), on the contrary, they are fundamental elements that guide the speaker-hearer interaction towards an appropriate interpretation of the pragmatics of discourse via an Adaptive Management process. Thus, it can be said that the procedure that Adaptive Management follows in discourse (assess problem, design, implement, monitor, evaluate, adjust) constitutes the circular cognitive path to use a discourse marker. The novelty of this model is that the notion of feedback is incorporated in the monitoring and evaluation stage, in case there is a need for adjustment which subsequently serves to start the process again.

1. Non-linear refers to the fact that discourse markers are not prepared or foreseen in the formal proposition but are interspersed by the speaker in the speech from a pragmatic repertoire. 
Other models of discourse that incorporate the idea of feedback - many of them based on Sinclair and Coulthard (1975) - are predominantly linear and concentrate on specific exchanges or transactions (this largely depends upon the terminology) and are viewed as stepping stones in the communication process. The model presented here, on the other hand, is based upon the hypothesis of a closed circular causal process which enables evolution while circularity is guaranteed (Maturana and Varela 1980). This concept, that the authors named "autopoiesis", describes the autonomy of the self-regulating elements ("auto") and their creation ("poiesis") inside the system. In the case of language, "autopoiesis" is manifest in the autonomy of discourse markers with respect to all kinds of syntactic, grammatical or semantic rules, and in the lack of constraints with regard to their presence or absence; and it is also manifest in the fact that discourse markers are always "created" within the system through the grammaticalisation of one (as in well, now) or more elements (you see, you know) in a particular language. In this sense, it is important to underline that discourse markers are language specific and that even a similar phonetic realisation in different languages of, for example, interjections does not guarantee their functional equivalence in discourse (Romero-Trillo 2000)

\section{Operative and Involvement Discourse Markers}

From a psycholinguistic perspective, the evolution of the cognitive capacity of a learner, in the first and in a foreign language, has to cope not only with the acquisition of the lexicon and the rules to manage it, but also with the pragmatic capacity to interact (agree, disagree, challenge, confirm, etc.). The failure to comply with the discourse demands posed by interaction often leads in second language learners to what I have termed "pragmatic fossilization" (Romero-Trillo 2002) when the interaction capacity does not match the grammatical and lexical competence, often due to sufficient lack of exposure to real language contexts. In the case of second language users, the absence of Adaptive Management skills can lead to what is often described as stilted or unnatural language.

In the case of discourse, Adaptive Management is the tool to reshape the cognitive stance of the speaker-listener in a given context through discourse markers. For this purpose, I propose the following typology:

- Operative Markers: the discourse markers that deal with the management of concepts and language comprehension to make the conversation flow without disruption. well, now, so, etc.

- Involvement Markers: the discourse markers that deal with the management of social rapport to safeguard the face of the interactants: you know, you see, I mean, etc.

This study will concentrate upon involvement markers because they can typically make the speaker follow Adaptive Management strategies when the addressee indicates that he/she is not following the cognitive or linguistic development of the speech. In fact, to describe these elements, we should make a preliminary distinction between those involvement discourse markers that overtly trigger Adaptive 
Management and those that do not. Those markers that do not precipitate this phenomenon are usually perceived as "rhetorical" (e.g. you know, you see, etc.) (for a global approach to this approach see for example Schiffrin, 1987), because they do not require a response from the listener, in contrast with others such as do you understand?. Nevertheless, overt Adaptive Management strategies occur when there is a real intention on the part of the speaker to verify the correct reception of his/her message. In this case, the particular relates to the appearance of other forms that can be an unequivocal signal - usually a rising intonation - for listeners that an answer that may serve to reshape discourse.

Another interest of this paper, in my opinion, is that the forms that will be analysed do not fit the traditional classification of discourse markers because my understanding of discourse markers has a wide scope, as I explained in Romero-Trillo (2001). In fact, I think that it is possible to incorporate new discourse markers to a language, no matter their core meaning, provided they are used in the appropriate functional and discourse slot. For this purpose, I shall differentiate between what I have described the "canonical" vs. the "pragmatic" use of certain expressions, where the latter stands for the realization of discourse markers (Romero-Trillo, 2002).

The Spanish discourse markers ${ }^{2}$ I will analyse are:

— ¿me entiendes? ('do you understand'); a Face Threatening Act (Brown and Levinson 1987) directed to the addressee to check if Adaptive Management is necessary

— ¿me explico? ('do I explain myself?'); where the responsibility of need to enact Adaptive Management lies on the speaker.

And the composites:

- Voy a ver si me explico/entiendes. ('let's see if I explain myself/ you can understand.')

- no sé si me explicolentiendes ('I don't know if I explain myself/you understand')

The English discourse markers are:

- I mean

- You see

- You know

\section{Analysis of the Data}

The present analysis will show the raw number of instances of the markers under study to illustrate their functions with a qualitative approach and will compare the Spanish and English results of the analysis by means of percentages to neutralize the disparity in their size.

2. For a general account of Spanish discourse markers see Portolés (1998), Martín Zorraquino and Portolés, (1999), Pons (1998); and also Vázquez (2003) on Spanish reception markers. 
The Spanish data for the analysis was obtained from the Corpus de Referencia del Español Actual (CREA), with 200 million words of Spanish speaking countries of both written and spoken language. For the present analysis only the Peninsular Spanish spoken section was selected (3,214,296 words). The forms under analysis stem from the expression me explico in its different forms: me explicol¿̈me explico?, no sé si me explico, and (vamos) a ver si me explico. Here follow some examples for each form.

\subsection{Spanish discourse markers}

The results of the analysis show that the expression me explico appears 24 times in the corpus and that 16 of the instances are discourse markers. Therefore, there is a preference in the use of this expression as a discourse marker, $66.6 \%$ of the cases, with a clear tendency to appear the declarative form: $81.5 \%$. Here follow some examples:

\section{a) Me explico / ¿Me explico?}

(1) ¡Bueno! Pues esta cubeta tiene una restricción, me explico, quiere decir de que tú cuando abres la el...

'Well! This bucket has on restriction, I explain myself, it means that when you open the'

(2) Alguna acción en la cual haya sido inconsecuente, ¿me explico? Entonces tenemos que pensar tenemos...

'Some action in which he was inconsequent, do I explain myself? Then we have to think we have to...'

\section{b) A ver si me explico/ Voy a ver si me explico}

(3) por qué siguen? Bueno, están curados... a ver si me explico, están curados físicamente.

'Why do they go on? Well, they are healed, let's see if I explain myself, they are physically healed.'

(4) los caballos de batalla hoy mayor. Voy a ver si me explico. Sí, cortito. Me dice Iñaki que muy corto.

'the biggest battle horses today. I'll see how to explain myself. Yes, shortish. Iñaki tells me that it's very short'

\section{c) No sé si me explico}

(5) arriba. Quizás te impide continuar. No sé si me explico. Sí, absolutamente, se encasilla le encas $* *$---

'above. Perhaps someone doesn't let you go on. I don't know if I am explaining myself. Yes, absolutely, you fit him...'

(6) persona y no te has dado cuenta de ella. No sé si me explico, quiero decirte Sí, sí, es decir, la...

'person, and you didn't notice her. I don't' know if I am explaining myself. I want to tell you. Yes, yes, that is to say...' 
The distribution of the instances in the corpus is the following:

- ¿Me explico? 3

- Me explico 5

- No sé si me explico 4

- A ver si me explico 3

- Voy a ver si me explico 1

From a suprasegmental perspective, it can be observed that the realisation of me explico in all its forms always precedes a pause, and very often encapsulates a tone group in itself, whilst the canonical use of the expression never ends a tone group and is often followed by a direct object that complements the ditransitivity of the verb: Personalmente yo no todavía no me explico cómo soy académico. Also, it is interesting to point out that the canonical meaning of the expression only appears with the form me explico and not with other combinations, and that in 50\% of the cases is accompanied by the negative form: no me explico.

The use of the form entiendes in its various combinations appears as follows:

\section{a) ¿Me entiendes?}

(7) a persona, quién iba a ganar realmente. Ya. ¿Me entiendes? Entonces, me di cuenta, en esa ciudad que ...

'by person, who was really to win. Yes, do you understand? Then I realised, in that town...

(8) para mi hija. Claro, eso sí supongo que ¿Me entiendes? Testigo y fruto de esa Exacto. Unión...

'for my daughter. Of course, that I suppose so. Do you understand? Witness and outcome of it. Right,union.

b) ¿Entiendes?

(9) Perdona, pues no no corre prisa Vale, de acuerdo. ¿entiendes? Vale vale entonces, $¡$ vale!

'Sorry, there's no hurry. Ok, fine. Understand? Ok, ok then. Ok!'

(10) volando también el plan de las municipales, ¿entiendes? O sea que Yo he ido también en esa dirección.

'also flying the organization of town-hall elections, understand? So, I have also gone in that direction'

c) Me entiendes, ¿no?

(11) días y y y te la daré ya toda completa”. Me entiendes, ¿no? Y, tengo, pues pues equipos había...

'days, and, and, and I will give you all'. You understand me, don't you? And I have, well, well, equipment'

(12) so yo no lo tengo, los pe and i. vale vale. Me entiendes, ¿no? Sí, sí. Pero vamos, todo lo que es...

'I don't have it, the pe and i, ok, ok, You understand me, don't you? Yes, yes, but everything....' 


\section{d) ¿Lo entiendes?}

(13) a un desequilibrio, estás desequilibradísima. ¿Lo entiendes o no? ¿Te te ha ocurrido alguna vez?

'An unbalance, you are very unbalanced. Do you understand it or not? Has it ever happened to you?'

(14) bambú, borla borla, ¿Lo entiendes? Bambú bambú, borla borla, 'bamboo, tassel, tassel Do you understand it or not?, bamboo, bamboo, tassel, tassel'

e) ¿Me entiendes lo que te digo?

(15) en esta casa no entra ni mi padre ni mi madre, ¿me entiendes lo que te digo? ¿Por qué? Porque mi madre e...

'Neither my father nor my mother will enter that house. Do you understand what I'm telling you? Why? Because my mother...'

(16) arriesgar. Pues no me arriesgo. No me arriesgo, ¿me entiendes lo que te digo? Y fíjate, me he comprado un...

'To risk. I won't risk. I won't risk. Do you understand what I'm telling you? And look, I have bought...'

\section{f) ¿Entiendes lo que te quiero decir?}

(17) ¿entiendes lo que te quiero decir? O sea, yo no es que...

'Do you understand what I want to tell you? That is, It is not that...'

(18) mi hermano y: si ves a una con un buen culo y ¿entiendes lo que te quiero decir? Sí, eso pasa en mi...

'my brother and, if you see one girl with a good bottom and Do you understand what I want to tell you? If that happens in my...'

\section{g) No sé si me entiendes}

(19) era, ¿me entiendes? porque a lo mejor no sé si me entiendes lo que te quiero decir, Tere.

'it was, do you understand? Because if perhaps I don't know if you understand what I want to tell you, Tere'

\section{h) A ver si me entiendes}

(20) Eso es, a ver si me entiendes, yo no tengo la culpa de si la botella imp... 'that's it, let's see if you understand me, I am not to blame if the bottle...'

(21) distintas posturas para hacer o sea, a ver si me entiendes, no. Pues claro que las hay.

'different opinions to do, that is, let's see if you understand me, no. Of course there are.'

The overall number of forms related to the form entiendes is 303 , of which 257 realize a discourse marker function. This means that $84.8 \%$ of the appearances of this form have a pragmatic function, of which $91.8 \%$ have an interrogative intonation. The quantitative results of the expressions are as follows: 
- ¿Me entiendes?

- ¿Entiendes?

- Entiendes, ¿no?

- ¿Lo entiendes?

— ¿Me entiendes lo que te digo?

- ¿Entiendes lo que quiero decir?

- No sé si me entiendes

- A ver si me entiendes
158

69

8

2

3

1

3

13 (2 of them with interrogative intonation)

\subsection{English discourse markers}

The English London-Lund Corpus (50,000 words) does not portray any instances of discourse markers that resemble the Spanish expressions presented above, even with semi-literal translations such as: "am I making myself clear'/'do I make myself clear', or of anything near to "am I explaining myself?'/'do I explain myself?', or even 'do you understand?', “do you see what I mean?', etc. English seems to prefer the discourse markers you know, you see (addressee-oriented) and I mean (speaker-oriented). Contrary to the formulaic variability of Spanish forms, the English expressions realise their meaning nuances via their prosodic variation.

\section{a) I mean}

The element I mean appears 175 times as a discourse marker in the corpus, of which $95.56 \%$ have falling ( () , level (=), or zero intonation contour. Of these, $2.22 \%$ indicate the start of the turn and the same percentage (2.22\%) offer the possibility of a reply from the addressee via rising intonation. Here follow some examples: ${ }^{3}$

$1435541011 \mathrm{~A} \quad 11$ this ^doesn`t 'say !whlat 'this 'is\# - . - /

$1435542011 \mathrm{~B} \quad 12 \wedge\left[\right.$ lindzh] ${ }^{\wedge}$ nineteen 'twenty-twlo\#

$1436543011 \mathrm{~B} \quad 11^{* \wedge}(($ thlat's 'not b/ad\#))*

$1436544011 \mathrm{~A} \quad 12$ *but $^{\wedge}$ where*. it`s ^so !blig \{lisn`t 'it\#\}\# /

1436545011 B 11 it`s ^gi!glantic $\{\wedge$ lisn`t *it\#*\}\#

$1436546011 \mathrm{~B} \quad 21$ ((I^mean)) /

(23)

$1164995011 \mathrm{~B} \quad 11 \wedge$ I've been cam!plaigning for th/at\#

$1164996011 \mathrm{~B} \quad 11$ for ^several !ylears n/ow\#

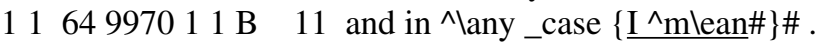

1164998012 B $11 \wedge^{\wedge}$ why !!shlould we $\left\{\wedge^{\wedge}\right.$ test the two things

$1164998011 \mathrm{~B} \quad 11$ toglether\#\}\#

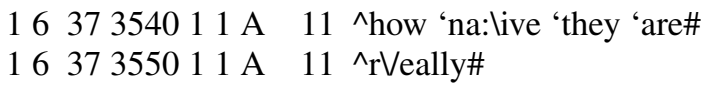

$1637355011 \mathrm{~A} \quad 11$ ^rVeally\#

3. The transcription conventions presented here are the original in the corpus. Only relevant features for the study are explained. 
$1637356011 \mathrm{~A} \quad 11$ ^how !easily 'taken /in\#

$1637357011 \mathrm{~B} \quad 11^{\wedge}[\mathrm{lm}] \#$

$1637358011 \mathrm{~A} \quad 11 \mathrm{I}$ ^m/ean\#.

I

I

$1637359012 \mathrm{~A} \quad 12$ to ^have a 'student 'come to you and [s] - ((oh)) /

$1637359011 \mathrm{~A} \quad 12 \wedge \mathrm{I}$ !read a blook\#

(25) $1431479011 \mathrm{~B} \quad 12$ well it`s ^sort of !tloo . ^yles\#

1431480011 B $20 *$ it`s*

$1432481011 \mathrm{~A} \quad 11 * \mathrm{I}^{* \wedge} \wedge \mathrm{m}=\mathrm{ean} \#$

1432482011 A 11 it ^ would _be a 'bit 'out of !pllace *s/omehow\#* /

1432483011 B $11 *^{*}$ yeah* ${ }^{\wedge}{ }^{\wedge}$ think it wlould\#

Prosodically speaking, the discourse marker I mean appears in the corpus with three possible tones, 0 (no tonicity), rising (/) and level (=). Frequently, tone 0 appears at the end of the tone group -although it also appears within the tone groupand indicates lack of expectancy of response from the addressee. On the contrary, the appearance of the level tone (=) always indicates the beginning of a tone group.

It is important to mention that this discourse marker can coexist with others, as in the next example where I mean and you know have a cumulative effect that merges the addressee-oriented and speaker-oriented Adaptive Management strategy. These combinations do not occur in Spanish.

$1214229011 \mathrm{~B} \quad 12$ 1at [dhi] . the !!literature\# - /

$1214230011 \mathrm{~B} 11$ I mean you know the ^actual !stlatements\# -

1214231013 B 111 [@:m] I^don`t think they`ve . they :ever in :fact /

$1214231012 \mathrm{~B} \quad 11$ 1em:bodied anything :quite as - :quite as /

1214231011 B 11 1far-:rleaching\#

\section{b) You see}

The discourse marker you see appears 116 times in the London-Lund Corpus and it always realizes the Adaptive Management function.

(27) $114458011 \mathrm{~B} \quad 11{ }^{\wedge}$ well there were [@] !Vone\#

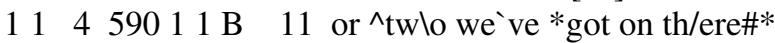

$11460011 \mathrm{~B} \quad 11{ }^{\wedge}$ you s/ee\#

11461011 A $11 * \wedge$ yes! ! slee\#*.

$11462011 \mathrm{~A} \quad 11^{\wedge} \mathrm{y}=\mathrm{es} \#$

(28) $15220011 \mathrm{~A} \quad 11 \mathrm{I}^{\wedge}$ rlead/English\#

15221011 A 11 but ${ }^{\wedge}$ only from :Kyd lonwards\#

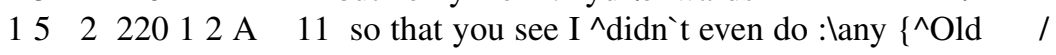

15222011 A $11 \backslash$ English\#\}\#

$15223011 \mathrm{~A} 11$ or ^\any Anglo-S/axon\#

$15224011 \mathrm{~A} \quad 11$ at ${ }^{\wedge}$ all\# 
(29)

$1639376011 \mathrm{~A} 11$ but $\wedge$ nlo\#

$1639377011 \mathrm{~A} 11$ ^you slee ‘[@:m]\# .

$1639378011 \mathrm{~A} 11\left[\right.$ [@] ${ }^{\wedge} \mathrm{n} / \mathrm{o \#}$

$1639379011 \mathrm{~A} \quad 12 \wedge$ this is $\wedge$ this is the :IVine\#

$1639380011 \mathrm{~A} \quad 11$ to ^((slell))\#

$1639381011 \mathrm{~A}$

11 ^obviously\# *_*

$1639382011 \mathrm{~A} \quad 11-$. $^{\wedge}$ and he "thinks that !I kn/ow\#

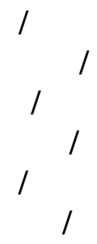

(30) $1131073011 \mathrm{~B} \quad 11$ there were ${ }^{\wedge}$ very flew\#

$1131074011 \mathrm{~B} \quad 11$ ((you know [@m]))^v^^ery 'few 'women\#

$1131075011 \mathrm{~B} \quad 11[$ [@m].^you s=ee\#

$1131076011 \mathrm{~B} \quad 11{ }^{\wedge}$ women :dVentists\#

$1131077011 \mathrm{~B} \quad 11$ in the ${ }^{\wedge}$ days when you :had to :p $\vee a y \#$

$1131078011 \mathrm{~B} \quad 11$ would $^{\wedge}$ never have 'made a !living\#

These examples show that this element can appear with several intonation contours: rising (/), falling (1), level (=) and zero (no tonicity). This indicates its prosodic polyvalence to signal a confirmation request (rising) -that must be followed by a reply from the addressee-; to signal strong statement (falling), or the more pragmatically neutral with level an zero tone. The use of the rising tone that requests confirmation (as in the first example) is of $44.83 \%$, which shows the almost equal ambivalence of this element to signal statement or to demand confirmation in this function.

\section{c) You know}

The element you know appears as a discourse marker 394 times in the LondonLund Corpus. Here follow some examples:

(31)

$1958560012 \mathrm{~A} \quad 11$ and ^that was 'when I !\{flirst 'met \} :poor 'Billy /

$1958560011 \mathrm{~A} \quad 11$ !Mlainbridge $\{\wedge$ tloo\# $\} \#$

$1958561011 \mathrm{~B} \quad 11{ }^{\wedge} \mathrm{W} V a s$ it\#

$1958562011 \mathrm{~A} \quad 11$ he was ^sitting in a :cVorner\#

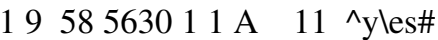

$1959564011 \mathrm{~A} 11$ and [@m].you ^kn/ow\#

$1959565011 \mathrm{~A} \quad 11 \wedge$ came up and 'intro!dVuced him'self\# -

1959566011 a $20[\mathrm{~m}]$

(32) $1961589011 \mathrm{~A} \quad 11$ you you ^knlow [dhi] . \{uni^vlersity\#\}\#

1962590011 a 20 there are two departments .

$1962591011 \mathrm{~A} \quad 11 \wedge[\mathrm{lm}] \#$.

1962592011 a 20 yeah

$1962593011 \mathrm{~A} \quad 11$ "^this "is a vlery 'bad th/ing\#

$1962594011 \mathrm{~A} \quad 12$ you ^knlow I . but ^n//obody\#

$1962595011 \mathrm{~A} \quad 11$ could do ^^anything $\left\{\mathrm{a}^{\wedge} \mathrm{b} /\right.$ out it\# $\}$ I

$1962596011 \mathrm{~A} \quad 11$ be^cause a :uni!versity com!mlittee was 'formed\# / 
2 1a $11161011 \mathrm{~B} \quad 112$ which ^have to $\mathrm{b}=\mathrm{e} \#$ -

2 1a $11162011 \mathrm{~B} \quad 112$ you ${ }^{\wedge} \mathrm{kn}=\mathrm{ow} \#$

2 1a $11163011 \mathrm{~B} \quad 112^{\wedge}$ put into :wlood\#

2 1a $11164011 \mathrm{~B} \quad 112$ and ${ }^{\wedge}$ thlingami_bobs\#

2 1a $11165011 \mathrm{~B} \quad 112$ and $^{\wedge}$ sent /over\# -

2 1a $11166011 \mathrm{~B} \quad 112^{\wedge}$ all at :great exp/ense\#

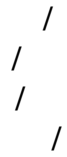

The examples provided above indicate that this element can appear with three possible intonation contours: falling ( () , rising (/) and level (=). As in the case of you see the appearance of the rising tone may trigger the response of the addressee:

\begin{tabular}{|c|c|}
\hline $1822232011 \mathrm{~B}$ & $11+\mathrm{I} \sup ^{\wedge} \mathrm{p} \bigvee$ ose it 'is\#+ \\
\hline $1822233011 \mathrm{~B}$ & 11 but $\wedge^{\text {they }}{ }^{`}$ re !too !blig you kn/ow\# \\
\hline $1822234011 \mathrm{~A}$ & $11 \wedge$ y/es\# \\
\hline $1822235011 \mathrm{~A}$ & 11 of $\wedge$ clo \\
\hline
\end{tabular}

The use of this element with a rising intonation that demands an answer from the addressee is $63.2 \%$ which indicates that it is primarily used by speakers with this aim.

\section{Discussion}

The quantitative results of the study presented above show that English and Spanish have different patterns in the construction of Adaptive Management in Discourse. Firstly, the amount of discourse markers that realise involvement in Spanish is much lower: 273 instances in the corpus $\left(8.493^{-3} \%\right)$, explico 16 examples and entiendes 257 examples. It must also be said that Spanish prefers the elements that have been studied here to the translation equivalents of the English markers, sabes, ves, es decir, which in a previous article (Romero-Trillo 2004) offered a frequency of $52,11,6$ - respectively - in the same corpus. Although the present study does not consider the behaviour of these three elements, if we added their appearances to the overall quantity the result would be $342\left(1.063^{-1} \%\right)$, compared to the results of English 685 (1.37\%) with the following distribution: I mean 175, you see 116, and you know 394. Taking into consideration the largest figure for Spanish, $1.063^{-1 \%}$, the English discourse markers outnumber 12,88 times the appearance of the Spanish ones.

The other fundamental difference is that Spanish makes a clear distinction with regard to the specialization of its markers that indicate statement or request for confirmation. The explico elements have a prevalence of $85 \%$ for statements, whereas the entiendes forms show a preference of $91.8 \%$ for interrogatives. Considering the raw numbers presented above, Spanish clearly favours the use of interrogatives and the request of confirmation in the use of involvement markers.

In English, on the other hand, we find a neat distribution of preference in the three discourse markers: I mean presents $95.56 \%$ of the instances for statements, you see, $55.17 \%$ for statements (44.83\% for requests) and you know, $63.2 \%$ for 
requests. Therefore, we can observe a cline in the specificity of use for each element which can be synthesised as follows:

\section{I mean
(statements) $\begin{gathered}\text { you see } \\ \text { (statements-requests) }\end{gathered} \quad \begin{aligned} & \text { you know } \\ & \text { (requests) }\end{aligned}$}

Also, it can be said that the basic difference between English and Spanish in the use of involvement discourse markers lies in their use as statements, since $I$ mean is almost comparatively much more frequent than the Spanish explico forms: $0.514 \%$ vs. $0.497^{-3} \%$, -more than one thousand times! As it seems obvious, this is a fundamental characteristic that students of English as a foreign language should bear in mind when they engage in Adaptive Management strategies. In the same vein, English uses the discourse markers you see and you know with largesse in statements, with no lexicalised equivalent in Spanish since entiendes forms only appear in the interrogative.

To conclude, the present article has tried to illustrate the phenomenon of Adaptive Management in Discourse as evidenced in the use of involvement discourse markers to show the great danger of pragmatic fossilization (Romero-Trillo 2002) if foreign learners misunderstand, misuse or do not take full advantage of the communicative possibilities that discourse markers represent for the correct cognitive development of conversation.

\section{References}

Brown, Penelope; Levinson, Stephen (1987). Politeness. Cambridge: Cambridge University Press.

Fischer, Kerstin (ed.) (2006). Approaches to Discourse Particles. Oxford: Elsevier. Martín Zorraquino, M. Antonia; Portolés, José (1999). "Los marcadores del discurso". In: Bosque, Ignacio; Demonte, Violeta (eds.). Nueva gramática descriptiva de la lengua española. Madrid: Espasa-Calpe vol. 3, pp. 4051-4213.

Maturana, Humberto; Varela, Francisco (1980). Autopoiesis and Cognition. Dortdrecht: D. Reidel.

McCulloch, Warren S.; Pitts, Walter H. (1943). "A logical calculus of the ideas immanent in nervous activity". Bulletin of Mathematical Biophysics 5: 115.

Pons Bordería, Salvador (1998). Conexión y conectores. Estudio de su relación en el registro informal de la lengua. València: Universitat de València, Cuadernos de Filología, Anejo XXVII.

Portolés, José (1998). Marcadores del discurso. Barcelona: Ariel.

Romero-Trillo, Jesús (1994). "Ahm, ehm, you call it theme?...A thematic approach to spoken English". Journal of Pragmatics 22: 495-509.

Romero-Trillo, Jesús (2000). "Systemic tools to establish appropriacy in discourse: the case of interjections in English and Spanish conversations". Revista Canaria de Estudios Ingleses 40: 59-75.

Romero-Trillo, Jesús (2001). "A mathematical model for the analysis of variation in discourse". Journal of Linguistics 37, 527-550. 
Romero-Trillo, Jesús (2002). "The pragmatic fossilization of discourse markers in nonnative speakers of English". Journal of Pragmatics 34: 769-784.

Romero-Trillo, Jesús (2004). "Subjective and Objective grounding in discourse markers". In: Aijmer, Karin (ed.). Dialogue Analysis VIII: Understanding and Misunderstanding in Dialogue. Tübingen: Niemeyer, pp. 185-197.

Romero-Trillo, Jesús (2006). "Discourse markers". In: Encyclopedia of Language and Linguistics. Oxford: Elsevier, pp. 639-642.

Schiffrin, Deborah (1987). Discourse Markers. Cambridge: Cambridge University Press.

Sinclair, John M.H; Coulthard, Malcolm (1975). Towards an Analysis of Discourse. Oxford: Oxford University Press.

Vázquez Veiga, Nancy (2003). Marcadores discursivos de recepción. Santiago de Compostela: Universidade de Santiago de Compostela.

\section{The corpora}

REAL ACADEMIA ESPAÑOLA: Banco de datos (CREA) [en línea]. Corpus de referencia del español actual. <http://www.rae.es> 14-9-06.

Svartvik, Jan; Quirk, Randolph (1980). The London-Lund Corpus. 